JURNAL MATEMATIKA. STATISTIKA \& KOMPUTASI

https-//journal.unhas.acid/indexphp/jmsk/index

Vol. 17, No. 2, 178-188, January, 2021

DOI: $10.20956 / j m s k . v 17 i 2.11710$

\title{
Application of Random Forest Method Classification to Predict BPJS Kesehatan Card Users Who Receive Contribution Assistance in Karangasem District, Bali Province 2017
}

\section{Penerapan Metode Random Forest dalam Pengklasifikasian Penerima Kartu BPJS Kesehatan Penerima Bantuan Iuran (PBI) di Kabupaten Karangasem, Provinsi Bali 2017}

\author{
Qonita Raihananda $^{1^{*}}$, I Wayan Edy Darma Putra ${ }^{2 *}$, Monica Seftaviani Sijabat ${ }^{3 *}$, Sifa \\ Rofatunnisa $^{4 *}$, Muhammad Ibnu Ma'ruf ${ }^{5^{*}}$, Hermarwan ${ }^{6 *}$, Rani Nooraeni ${ }^{*}$
}

\begin{abstract}
BPJS Kesehatan is a social security facility provided by the government to all people who are registered as members. BPJS Kesehatan membership is divided into two, namely BPJS for Contribution Assistance Recipients (BPJS PBI) and BPJS Non-Contribution Assistance Recipients (BPJS Non-PBI). In 2019, Bali Province is targeted to achieve Universal Health Coverage of 95 percent so that the Bali Provincial Government has budgeted funds worth IDR 945 billion to finance JKN - KBS services which are integrated with JKN - KIS. Karangasem is one of the four districts in Bali Province that received the most percentage of financing, which is 51 percent of the total budget needed when compared to other areas. This study aims to classify the BPJS-PBI recipient community based on education variables, employment indicators, age, and per capita expenditure in Karangasem Regency in 2017. The classification method used in this study is the random forest method. The results showed that the per capita expenditure variable had the largest contribution in classifying the status of PBI participants. The model that is formed produces an accuracy of 0.8017 . This means that the model can predict 80.17 percent testing data correctly.
\end{abstract}

Keywords: BPJS Kesehatan PBI, Karangasem, Classification, Random Forest.

\begin{abstract}
Abstrak
BPJS Kesehatan merupakan fasilitas jaminan sosial yang diberikan oleh pemerintah kepada seluruh masyarakat yang terdaftar sebagai anggota. Keanggotaan BPJS Kesehatan dibagi menjadi dua, yaitu BPJS

${ }^{*}$ Politeknik Statistika STIS

Email: ${ }^{1}$ qraihananda@gmail.com, ${ }^{2}$ edydarma1602@gmail.com, ${ }^{3}$ monica.seftaviani21@ gmail.com, ${ }^{4}$ sifarofatunnisa24@gmail.com, ${ }^{5} 211709857 @$ stis.ac.id, ${ }^{6}$ hermarwanofficial@gmail.com, raninoor@stis.ac.id (c) (i) \&
\end{abstract}

This work is licensed under a Creative Commons Attribution-NonCommercial 4.0 International License 


\section{Qonita Raihananda, I Wayan Edy Darma Putra, Monica Seftaviani Sijabat, Sifa Rofatunnisa, Muhammad Ibnu Ma'ruf, Hermarwan, Rani Nooraeni Jurnal Matematika, Statistika E Komputasi}

Penerima Bantuan Iuran (PBI) dan BPJS Non Penerima Bantuan Iuran (BPJS Non PBI). Pada tahun 2019, Provinsi Bali ditargetkan mencapai Universal Health Coverage sebesar 95 persen sehingga Pemerintah Provinsi Bali menganggarkan dana senilai Rp 945 miliar untuk pembiayaan layanan JKN - KBS yang diintegrasikan dengan JKN - KIS. Karangasem merupakan salah satu dari empat kabupaten di Provinsi Bali yang mendapatkan persentase pembiayaan paling banyak, yaitu sebesar 51 persen dari total anggaran yang dibutuhkan jika dibandingkan dengan wilayah lainnya. Penelitian ini bertujuan untuk mengklasifikasikan masyarakat penerima BPJS-PBI berdasarkan variabel pendidikan, indikator ketenagakerjaan, usia, dan pengeluaran per kapita di Kabupaten Karangasem tahun 2017. Metode klasifikasi yang digunakan dalam penelitian ini adalah metode random forest. Hasil penelitian menunjukan bahwa variabel pengeluaran per kapita memiliki kontribusi terbesar dalam mengklasifikasikan status peserta PBI. Model yang terbentuk menghasilkan akurasi sebesar 0, 8017. Hal ini berarti model dapat mengklasifikasikan dengan tepat sebesar 80, 17 persen.

Kata kunci: BPJS Kesehatan PBI, Karangasem, Klasifikasi, Random Forest.

\section{PENDAHULUAN}

Universal Health Coverage (UHC) merupakan suatu program pemerintah yang bertujuan untuk menjamin tersedianya jaminan kesehatan bagi seluruh lapisan masyarakat, tanpa terhalang gangguan finansial. Guna mewujudkan program tersebut, pemerintah semakin gencar dalam meningkatkan target jumlah peserta program Jaminan Kesehatan Nasional-Kartu Indonesia Sehat (JKN-KIS) di berbagai daerah. Dalam hal ini, Badan Penyelenggara Jaminan Sosial (BPJS) Kesehatan menjadi badan yang bertugas sebagai penyelenggara. Peserta program BPJS Kesehatan terbagi menjadi dua kategori, yaitu peserta BPJS Kesehatan yang merupakan Penerima Bantuan Iuran (PBI) dan peserta BPJS Kesehatan yang bukan Penerima Bantuan Iuran atau yang biasa disebut dengan BPJS Kesehatan Non PBI. Secara garis besar, perbedaan antara BPJS Kesehatan PBI dengan Non PBI adalah para peserta PBI, iuran bulanannya dibayarkan oleh pemerintah. Sedangkan peserta Non PBI merupakan peserta BPJS Kesehatan yang iuran bulanannya dibayar sendiri oleh peserta. Peserta yang berhak menjadi peserta program jaminan kesehatan PBI terdiri dari 2 golongan yaitu fakir miskin dan orang tidak mampu [3]. Penentuan keikutsertaan program ini, didasarkan pada Data Terpadu Kesejahteraan Sosial (DTKS).

Pada tahun 2019, Provinsi Bali ditargetkan mencapai Universal Health Coverage sebesar 95 persen sehingga Pemerintah Provinsi Bali menganggarkan dana senilai Rp945 miliar untuk pembiayaan layanan JKN - KBS yang diintegrasikan dengan JKN - KIS. Untuk memenuhi target tersebut, Pemerintah Provinsi Bali telah menyiapkan skema pembagian pembiayaan dengan pemerintah kabupaten maupun pemerintah kota.

Karangasem merupakan salah satu dari empat kabupaten di Provinsi Bali yang mendapatkan persentase pembiayaan paling banyak, yaitu sebesar 51 persen dari total anggaran yang dibutuhkan jika dibandingkan dengan wilayah lainnya; Gianyar yang hanya mendapat 40 persen, Klungkung yang mendapat pembiayaan sebesar 49 persen, dan Denpasar yang sama sekali tidak mendapatkan bantuan pembiayaan [11]. Besarnya persentase bantuan pembiayaan yang diterima Pemerintah Kabupaten Karangasem disebabkan karena Karangasem merupakan kabupaten yang tingkat kemiskinannya pada tahun 2017 menunjukkan angka paling tinggi jika dibandingkan daerah lainnya, yakni sebesar 6,55 persen [5]. Salah satu faktor penyebab terjadinya kemiskinan adalah pendidikan yang diperoleh. Data BPS menunjukkan persentase penduduk di Kabupaten 


\section{Qonita Raihananda, I Wayan Edy Darma Putra, Monica Seftaviani Sijabat, Sifa Rofatunnisa, Muhammad Ibnu Ma'ruf, Hermarwan, Rani Nooraeni Jurnal Matematika, Statistika \& Komputasi}

Karangasem dengan pendidikan tertinggi yang ditamatkan SD sederajat dan tidak pernah bersekolah mencapai 64,38 persen dari total penduduk selama periode 2016-2018.

Rendahnya tingkat pendidikan menyebabkan pekerja memilih sektor informal [12] yang umumnya menggunakan teknologi yang sederhana sehingga biasanya sektor ini dikenal sebagai sektor dengan kondisi kerja tidak layak dan tingkat pendapatan rendah [7]. Tingginya kemiskinan juga dapat dipengaruhi oleh banyaknya penduduk yang memiliki rata-rata pengeluaran per kapita per bulan di bawah Garis Kemiskinan. Rendahnya pendapatan menyebabkan tingkat partisipasi angkatan kerja semakin tinggi karena penduduk lebih memilih bekerja dibandingkan bersekolah dan mengurus rumah tangga [8]. Selama periode 2015 - 2018, persentase Tingkat Partisipasi Angkatan Kerja (TPAK) di Kabupaten Karangasem memberikan nilai rata-rata sebesar 81 persen dengan jumlah penduduk yang bekerja lebih tinggi dibandingkan penduduk yang bersekolah dan mengurus rumah tangga [6]. Dengan tingginya tingkat kemiskinan di Kabupaten Karangasem disertai dengan besarnya kontribusi penduduk yang bekerja dan rendahnya tingkat pendidikan diharapkan pemerintah mampu memberikan berbagai jaminan perlindungan, termasuk salah satunya jaminan kesehatan bagi masyarakat yang kurang mampu melalui program BPJS PBI.

Berdasarkan paparan latar belakang di atas, maka penelitian ini bertujuan untuk mengklasifikasikan masyarakat penerima BPJS Kesehatan PBI berdasarkan variabel pendidikan, indikator ketenagakerjaan, usia, dan pengeluaran per kapita di Kabupaten Karangasem tahun 2017. Metode klasifikasi yang digunakan adalah metode random forest. Metode ini dipilih karena dapat digunakan pada data yang timpang (imbalanced data) dan memiliki kesalahan (error) yang lebih kecil [9]. Metode random forest tetap dapat digunakan bila terdapat missing data dan secara umum metode ini memiliki akurasi yang cukup tinggi dibanding metode yang lain [10].

\section{TINJAUAN PUSTAKA}

\subsection{BPJS Kesehatan PBI}

Badan Penyelenggara Jaminan Sosial (BPJS) Kesehatan merupakan badan publik yang menyelenggarakan program Jaminan Kesehatan. Peserta BPJS Kesehatan terdiri dari dua kelompok, yaitu Penerima Bantuan Iuran (PBI) dan Bukan Penerima Bantuan Iuran (Non PBI) Jaminan Kesehatan. PBI adalah peserta Jaminan Kesehatan bagi fakir miskin dan orang tidak mampu sebagaimana diamanatkan UU SJSN yang iurannya dibayari pemerintah sebagai peserta program Jaminan Kesehatan (BPJS Kesehatan [4].

\subsection{Random Forest Clustering}

Random forest merupakan metode klasifikasi berbasis decision tree dengan output dari hasil klasifikasinya berupa decision mayoritas dari seluruh trees yang terbentuk. Random forest membentuk sekumpulan pohon keputusan (decision trees) pada subruang data secara acak untuk membangun prediktor, sehingga menghasilkan satu set pohon keputusan berdasarkan modus tiaptiap pohon [9].

Random forest merupakan metode klasifikasi berbasis pohon keputusan. Metode ini menghasilkan banyak trees yang dibentuk dari sampel-sampel training set. Hasil akhirnya adalah 


\section{Qonita Raihananda, I Wayan Edy Darma Putra, Monica Seftaviani Sijabat, Sifa Rofatunnisa, Muhammad Ibnu Ma'ruf, Hermarwan, Rani Nooraeni Jurnal Matematika, Statistika \& Komputasi}

decision mayoritas dari seluruh trees yang terbentuk. Pada metode random forest, terdapat proses bagging, yaitu training set akan disampel dengan pengembalian sehingga dihasilkan beberapa decision tree. Decision yang paling banyak terpilih oleh trees akan menjadi keputusan klasifikasi akhir. Kelebihan metode random forest antara lain cocok digunakan pada training set yang besar, dapat digunakan pada data set yang mengandung missing data, dan secara umum memiliki akurasi yang lebih tinggi dibanding metode yang lain. Sedangkan kekurangannya adalah waktu pembuatan model yang lama (bergantung pada banyaknya decision trees yang dihasilkan) [10].

Adapun langkah-langkah yang dilakukan dalam melakukan analisis random forest adalah sebagai berikut:

1. Membagi data menjadi data training dan data testing.

2. Melakukan proses bagging, yaitu dilakukan penarikan sampel pada data training menggunakan metode random sampling with replacement. Setiap sampel dari data training akan menghasilkan satu tree. Proses bagging dilakukan berulang sesuai jumlah trees yang ingin dibuat. Satu objek pada data testing diproses pada seluruh trees yang telah dibuat.

3. Membangun model random forest dengan data training hasil dari proses bagging dan melakukan prediksi dengan mengombinasikan hasil dari setiap decision trees/pohon keputusan dengan cara voting.

4. Melakukan pengujian pada model yang dibangun dengan mengapliaksikannya pada data testing.

5. Membuat tabel confusion matrix (matriks kebingungan) dan melakukan evaluasi model random forest dengan menggunakan beberapa parameter, yaitu akurasi data training dan akurasi data testing.

\subsection{Confusion Matrix}

Confusion Matrix menyajikan jumlah data yang diklasifikasikan dengan benar dan salah berdasarkan model yang terbentuk dan data yang sebenarnya (actual values). Kelas positif yang diprediksi dengan benar oleh model dinamakan True Positive (TP). Sedangkan, kelas negative yang diprediksi benar oleh model dinamakan True Negative (TN). Kelas positif yang diprediksi salah oleh model dinamakan False Negative (FN). Sedangkan, kelas negatif yang diprediksi salah oleh model dinamakan False Positive (FP). Struktur Confusion Matrix dapat diihat pada Tabel 2.1.

Tabel 2.1 Confusion Matrix

\begin{tabular}{|l|l|l|}
\hline \multirow{2}{*}{$\begin{array}{l}\text { Kelas } \\
\text { Prediksi }\end{array}$} & \multicolumn{2}{|l|}{ Kelas Aktual } \\
\cline { 2 - 3 } Positif & Negatif \\
\hline Positif & TP & FP \\
\hline Negatif & FN & TN \\
\hline
\end{tabular}

Berdasarkan Confusion Matrix, diketahui beberapa indikator yang dapat digunakan untuk mengukur kinerja model yang telah terbentuk, salah satunya adalah Accuracy. Nilai Accuracy menggambarkan seberapa baik model dalam mengklasifikasikan seluruh data dengan benar. Nilai ini diperoleh dari rasio antara jumlah data yang diklasifikasikan benar oleh model (TP dan TN) dengan jumlah keseluruhan data $(\mathrm{TP}+\mathrm{FP}+\mathrm{FN}+\mathrm{TN})[1]$. 


\section{Qonita Raihananda, I Wayan Edy Darma Putra, Monica Seftaviani Sijabat, Sifa Rofatunnisa, Muhammad Ibnu Ma'ruf, Hermarwan, Rani Nooraeni Jurnal Matematika, Statistika \& Komputasi}

\section{METODE PENELITIAN}

\subsection{Sumber Data dan Variabel Penelitian}

Penelitian ini menggunakan data sekunder yang bersumber dari Survei Sosial Ekonomi Nasional (Susenas) tahun 2017 di Kabupaten Karangasem, Bali. Variabel-variabel yang digunakan dalam pengklasifikasian peserta BPJS PBI ini adalah pendidikan, indikator ketenagakerjaan, usia, dan pengeluaran per kapita di Kabupaten Karangasem. Berikut ini adalah tabel ringkasan variabelvariabel penelitian yang digunakan.

Tabel 3.1 Variabel-variabel Penelitian

\begin{tabular}{|l|l|l|}
\hline \multicolumn{1}{|c|}{ Variabel } & \multicolumn{1}{c|}{ Tipe Data } & \multicolumn{1}{c|}{ Deskripsi } \\
\hline $\begin{array}{l}\text { Pendidikan } \\
\text { terakhir }\end{array}$ & Polynomial & $\begin{array}{l}\text { Jenjang pendidikan tertinggi yang } \\
\text { sedang/pernah diikuti oleh masyarakat } \\
\text { (tidak/belum pernah sekolah, SD, SMP, } \\
\text { SMA, atau PT). }\end{array}$ \\
\hline $\begin{array}{l}\text { Indikator } \\
\text { ketenagakerjaan }\end{array}$ & Polynomial & $\begin{array}{l}\text { Indikator ketenagakerjaan terdiri dari } \\
\text { penduduk yang termasuk angkatan kerja } \\
\text { (bekerja dan tidak bekerja) dan penduduk } \\
\text { yang tidak termasuk angkatan kerja } \\
\text { (sekolah, mengurus rumah tangga, dan } \\
\text { kegiatan lainnya). }\end{array}$ \\
\hline Usia & Numerik & Usia masyarakat \\
\hline Exp & Numerik & Pengeluaran per kapita per bulan \\
\hline $\begin{array}{l}\text { Status peserta } \\
\text { PBI }\end{array}$ & Label & Terima, tidak \\
\hline
\end{tabular}

\subsection{Prosedur Analisis}

Penelitian ini menggunakan aplikasi R versi 4.2 dan Microsoft Excel untuk mengolah datanya. Berikut ini prosedur analisis dalam pengklasifikasian peserta BPJS Kesehatan berdasarkan status PBI dan non PBI.

1. Melakukan analisis secara deskriptif mengenai data-data pendidikan, indikator ketenagakerjaan, usia, dan pengeluaran per kapita peserta BPJS Kesehatan di Kabupaten Karangasem.

2. Proses klasifikasi dimulai dengan melakukan proses persiapan pengolahan data (preprocessing) terlebih dahulu. Proses persiapan ini terdiri dari proses pembersihan data, penyeleksian variabel, dan transformasi pada beberapa variabel kategorik. Proses pembersihan data (data cleansing) merupakan salah satu proses yang penting untuk dilakukan pada tahap awal dalam pengolahan data. Proses ini bertujuan untuk menghilangkan noise dan data yang tidak relevan dengan penelitian yang dilakukan. Selanjutnya dilakukan penyeleksian data-data yang dibutuhkan berdasarkan variabelvariabel yang telah disebutkan pada tabel 1 . Setelah pemilihan data, dilakukan proses 
Qonita Raihananda, I Wayan Edy Darma Putra, Monica Seftaviani Sijabat, Sifa

Rofatunnisa, Muhammad Ibnu Ma'ruf, Hermarwan, Rani Nooraeni

Jurnal Matematika, Statistika \& Komputasi

transformasi data. Transformasi dilakukan pada kelompok data variabel pendidikan terakhir, dimana data-data tersebut dikelompokkan ke dalam lima kategori.

3. Setelah dilakukan proses persiapan pengolahan data, tahapan yang dilakukan selanjutnya adalah melakukan proses klasifikasi dengan menggunakan metode random forest.

4. Melakukan penarikan kesimpulan.

\section{HASIL DAN PEMBAHASAN}

\subsection{Statistik Deskriptif}

\subsubsection{Distribusi Masyarakat berdasarkan Status Penerima PBI dan Pendidikan Terakhir}

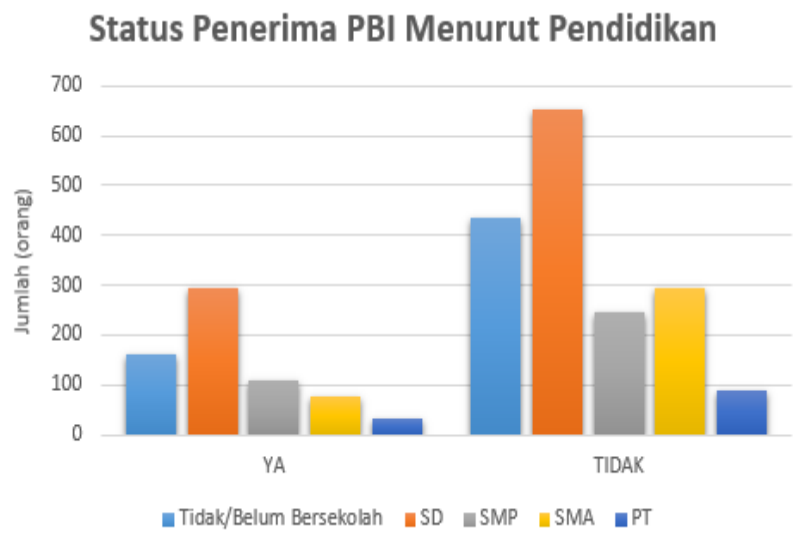

Grafik 4.1.1 Distribusi Masyarakat berdasarkan Status PBI dan Tingkat Pendidikan

Berdasarkan grafik 4.1.1, dapat dilihat bahwa masyarakat di Kabupaten Karangasem lebih banyak yang berstatus bukan peserta Penerima Bantuan Iuran (PBI). Jika dilihat dari tingkat pendidikannya, masyarakat yang berstatus sebagai peserta PBI didominasi oleh mereka yang sedang dan telah menyelesaikan pendidikan SD. Sama halnya dengan masyarakat yang berstatus sebagai peserta PBI, masyarakat yang berstatus bukan peserta PBI paling banyak berada pada tingkat pendidikan SD. Dapat dilihat juga berdasarkan tingkat pendidikannya, masyarakat yang berstatus sebagai peserta PBI memiliki pola yang cenderung sama dengan masyarakat yang berstatus sebagai peserta Non-PBI.

\subsubsection{Distribusi Masyarakat berdasarkan Status Penerima PBI dan Indikator}

Ketenagakerjaan 


\section{Qonita Raihananda, I Wayan Edy Darma Putra, Monica Seftaviani Sijabat, Sifa Rofatunnisa, Muhammad Ibnu Ma'ruf, Hermarwan, Rani Nooraeni Jurnal Matematika, Statistika \& Komputasi}

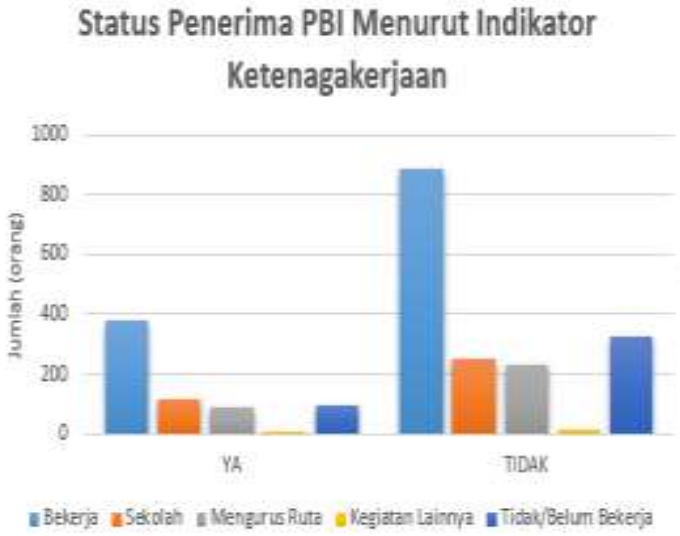

Grafik 4.1.2 Distribusi Masyarakat berdasarkan Status PBI dan Indikator Ketenagakerjaan

Dari grafik 4.1.2, dapat ditunjukkan bahwa masyarakat bukan Penerima Bantuan Iuran (PBI) lebih banyak dibandingkan masyarakat Penerima Bantuan Iuran (PBI). Berdasarkan indikator ketenagakerjaannya, baik masyarakat Penerima Bantuan Iuran maupun yang bukan Penerima Bantuan Iuran paling banyak berasal dari mereka yang berstatus bekerja. Kedua kelompok peserta Penerima Bantuan Iuran dan bukan Penerima Bantuan Iuran berdasarkan indikator ketenagakerjaannya menunjukkan pola yang cenderung sama.

\subsubsection{Distribusi Usia Masyarakat berdasarkan Status Penerima PBI}

\section{Distribusi Usia}

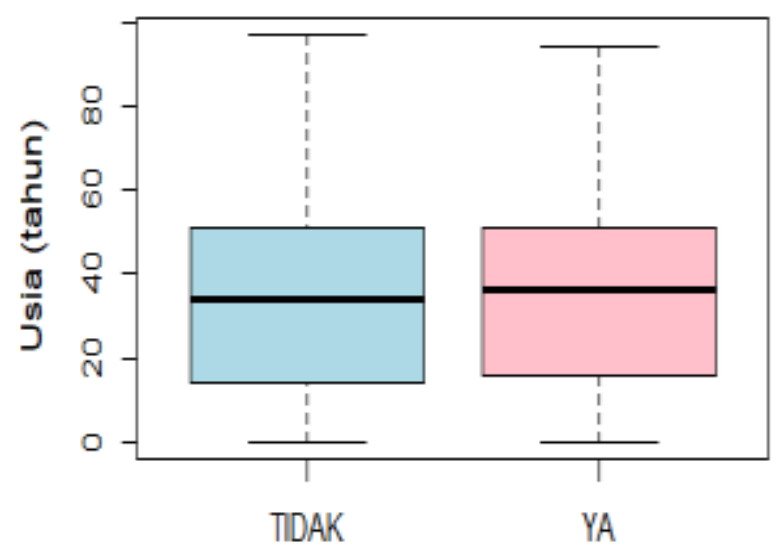

$\mathrm{PB} \mid$

Grafik 4.1.3 Distribusi Usia Masyarakat berdasarkan Status PBI 


\section{Qonita Raihananda, I Wayan Edy Darma Putra, Monica Seftaviani Sijabat, Sifa Rofatunnisa, Muhammad Ibnu Ma'ruf, Hermarwan, Rani Nooraeni Jurnal Matematika, Statistika \& Komputasi}

Berdasarkan grafik 4.1.3, terlihat bahwa nilai tengah (median) dari distribusi usia peserta BPJS Kesehatan yang tidak berstatus PBI adalah 34 tahun, sedangkan nilai tengah (median) dari distribusi usia peserta BPJS Kesehatan yang berstatus PBI adalah 36 tahun. Usia termuda peserta BPJS Kesehatan yang tidak berstatus PBI dan yang berstatus PBI adalah 0 tahun. Usia tertua peserta BPJS Kesehatan yang tidak berstatus PBI adalah 97 tahun, sedangkan usia tertua peserta BPJS Kesehatan yang berstatus PBI adalah 94 tahun.

\subsubsection{Distribusi Pengeluaran Per Kapita Masyarakat berdasarkan Status Penerima PBI}

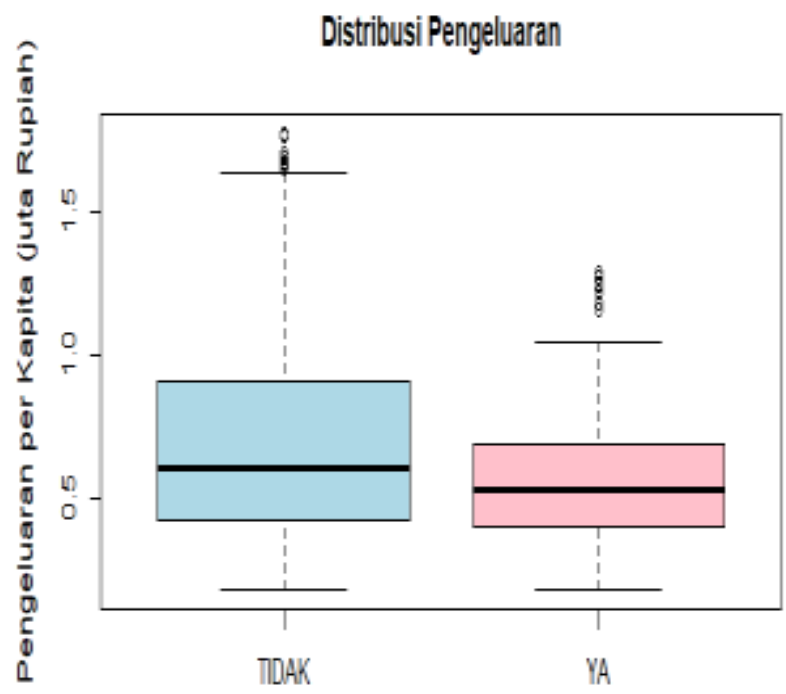

PBI

Grafik 4.1.4 Distribusi Pengeluaran Masyarakat berdasarkan Status PBI

Berdasarkan grafik 4.1.4, terlihat bahwa nilai tengah (median) dari distribusi pengeluaran per kapita (rupiah) peserta BPJS Kesehatan yang tidak berstatus PBI adalah Rp603.007,00. Sedangkan nilai tengah (median) dari distribusi pengeluaran per kapita (rupiah) peserta BPJS Kesehatan yang berstatus PBI adalah Rp525.757,00. Pengeluaran terendah peserta BPJS Kesehatan yang tidak berstatus PBI dan yang berstatus PBI adalah Rp175.949,00. Pengeluaran tertinggi peserta BPJS Kesehatan yang tidak berstatus PBI adalah Rp1.778.087,00. Sedangkan pengeluaran tertinggi peserta BPJS Kesehatan yang berstatus PBI adalah Rp1.289.176,00. 


\section{Qonita Raihananda, I Wayan Edy Darma Putra, Monica Seftaviani Sijabat, Sifa Rofatunnisa, Muhammad Ibnu Ma'ruf, Hermarwan, Rani Nooraeni Jurnal Matematika, Statistika \& Komputasi}

\subsection{Klasifikasi Random Forest}

\subsubsection{Important Variable}

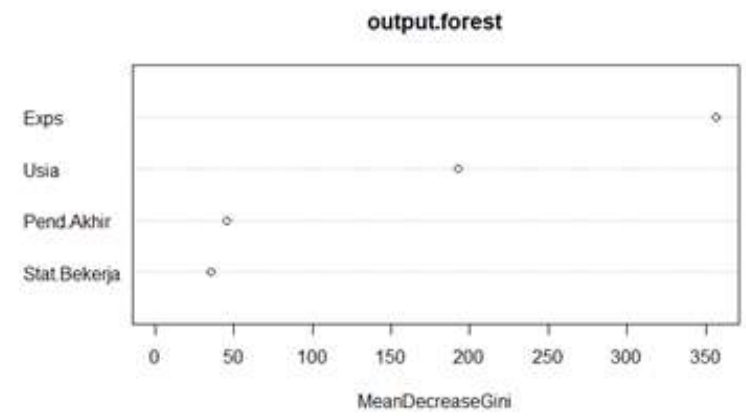

Grafik 4.2.1 Important Variable

Besarnya kontribusi suatu variabel dapat dilihat melalui nilai Mean Decrease Gini. Nilai mean decrease gini yang tinggi menunjukkan kontribusi variabel tersebut juga besar dalam model. Berdasarkan model random forest yang telah dihasilkan pada penelitian ini, dapat terlihat dalam grafik 4.2.1, bahwa variabel Exp (pengeluaran) memiliki kontribusi terbesar dalam memengaruhi variabel status peserta PBI. Hal ini ditunjukkan oleh nilai mean decrease gini variabel Exp lebih besar daripada variabel lainnya. Dapat dikatakan bahwa semakin rendah pendapatan seseorang akan sangat berpengaruh terhadap keikutsertaannya sebagai peserta BPJS PBI.

\subsubsection{Klasifikasi peserta BPJS Kesehatan berdasarkan status PBI dan non-PBI}

Tabel 4.2.2 Consufion Matrix

\begin{tabular}{|c|c|c|}
\hline \multirow{2}{*}{ Kelas Prediksi } & \multicolumn{2}{|c|}{ Kelas Aktual } \\
\cline { 2 - 3 } & Tidak & Ya \\
\hline Tidak & 393 & 50 \\
\hline Ya & 64 & 68 \\
\hline
\end{tabular}




\section{Qonita Raihananda, I Wayan Edy Darma Putra, Monica Seftaviani Sijabat, Sifa Rofatunnisa, Muhammad Ibnu Ma'ruf, Hermarwan, Rani Nooraeni Jurnal Matematika, Statistika \& Komputasi}

Berdasarkan tabel 4.2.2, sebanyak 393 data peserta BPJS non-PBI dan 68 data peserta BPJS PBI diklasifikasikan secara benar oleh model yang terbentuk. Sedangkan 64 data peserta BPJS nonPBI salah diklasifikasikan menjadi peserta BPJS PBI (false positive) dan 50 data peserta BPJS PBI salah diklasifikasikan menjadi peserta BPJS non-PBI (false negative). Confusion matrix di atas menghasilkan akurasi sebesar 0, 8017. Hal ini berarti model yang terbentuk mampu memprediksi data testing sebesar 80, 17 persen secara tepat. Data testing yang digunakan sebesar 20 persen dari keseluruhan observasi untuk memvalidasi model yang telah terbentuk.

\section{KESIMPULAN}

Hasil penelitian menunjukkan bahwa peserta BPJS Kesehatan berstatus PBI di wilayah Kabupaten Karangasem dapat diklasifikasikan menurut variabel pengeluaran per kapita, pendidikan terakhir, indikator ketenagakerjaan, dan usia. Pengeluaran per kapita memiliki kontribusi pengaruh terbesar, selanjutnya diikuti oleh usia, dan pendidikan terakhir. Output confusion matrix menunjukan bahwa observasi yang tidak diprediksi dengan tepat oleh model proporsinya sebesar 19,83 persen dari total data testing. Sedangkan angka 0,8017 menunjukkan model tersebut mampu memprediksi data testing dengan tepat sebesar 80,17 persen.

\section{DAFTAR PUSTAKA}

[1] Amir, S. \& Prasetyo B. (2020). Comparison of Elliptic Envelope Method and Isolation Forest Method on Imbalance Dataset. Jurnal Matematika, Statistika, dan Komputasi, 17(1), 42-49. DOI : $10.20956 /$ jmsk.v\%vi\%i.10899

[2] BPJS Kesehatan. (2016). Peserta Program JKN. Diunduh dari https://faskes.bpjskesehatan.go.id/aplicares/\#/app/peta pada tanggal 13 Oktober 2020.

[3] BPJS Kesehatan. (2020). Peserta BPJS. Diunduh dari https://bpjskesehatan.go.id/bpjs/pages/detail/2014/11 pada tanggal 13 Oktober 2020.

[4] BPJS Kesehatan. (2020). Seputar BPJS Kesehatan. Diunduh dari https://bpjskesehatan.go.id/bpjs/dmdocuments/eac4e7a830f58b4ade926754f74b6caf.pdf pada tanggal 29 Oktober 2020. 


\section{Qonita Raihananda, I Wayan Edy Darma Putra, Monica Seftaviani Sijabat, Sifa Rofatunnisa, Muhammad Ibnu Ma'ruf, Hermarwan, Rani Nooraeni Jurnal Matematika, Statistika \& Komputasi}

[5] BPS. (2018). Persentase Penduduk Miskin Provinsi Bali menurut Kabupaten/Kota. Diunduh dari https://bali.bps.go.id/indicator/23/125/1/persentase-penduduk-miskin-provinsi-balimenurut-kabupaten-kota.html pada tanggal 13 Oktober 2020.

[6] BPS. (2019). Indikator Ketenagakerjaan Kabupaten Karangasem. Diakses dari https://karangasemkab.bps.go.id/indicator/6/93/1/indikator-ketenagakerjaan-kabupatenkarangasem.html pada tanggal 14 Oktober 2020.

[7] Diana, F. N. (2019). Pekerja Informal dan Kemiskinan di Bekasi. Diunduh dari http://m.ayobekasi.net/read/2019/05/20/2805/pekerja-informal-dan-kemiskinan-di-kabupatenbekasi pada tanggal 12 Oktober 2020.

[8] Fudloli, M. T., \& Sukidin. (2015). Tingkat Partisipasi Angkatan Kerja Masyarakat Miskin di RT.01 RW.06 Desa Tegal Gede Kecamatan Sumbersari Kabupaten Jember. Jurnal Pendidikan Ekonomi, 9(2), 15-25. Diakses dari https://jurnal.unej.ac.id/index.php/JPE/article/view/3368

[9] Nisa, I. M. K., \& Nooraeni, R. (2020). Penerapan Metode Random Forest Untuk Klasifikasi Wanita Usia Subur di Perdesaan Dalam Menggunakan Internet (SDKI 2017). Jurnal Matematika Dan Statistika Serta Aplikasinya, 8(1), 72-76. DOI: https://doi.org/10.24252/msa.v8i1.13162f

[10] Pramana, S., Yuniarto, B., Mariyah, S., Santoso, I., Nooraeni, R. (2018). Data Mining dengan R: Konsep serta Implementasi. Bogor: In Media.

[11] Wiratmini, N. E. (2018). Targetkan UHC 95\% pada 2019, Bali Anggarkan Rp495 Miliar untuk Pembiayaan JKN. Diunduh dari Bali Bisnis: https://bali.bisnis.com/read/20181231/537/874159/targetkan-uhc-95-pada-2019-balianggarkan-rp495-miliar-untuk-pembiayaan-jkn pada tanggal 14 Oktober 2020.

[12] Yuniati, M. (2020). Analisis Ekonomi Angkatan Kerja Perempuan Berdasarkan Tingkat Pendidikan Diploma dan Universitas di Provinsi NTB Tahun 2016 - 2018. Jurnal Bina Ilmiah, 14(6), 2703-2710. DOI : https://doi.org/10.33758/mbi.v14i6.416 